This PDF is a selection from a published volume from the National Bureau of Economic Research

Volume Title: Agglomeration Economics

Volume Author/Editor: Edward L. Glaeser, editor

Volume Publisher: The University of Chicago Press

Volume ISBN: 0-226-29789-6

Volume URL: http://www.nber.org/books/glae08-1

Conference Dates: November 30-December 1, 2007

Publication Date: February 2010

Chapter Title: New Evidence on Trends in the Cost of Urban Agglomeration

Chapter Author: Matthew E. Kahn

Chapter URL: http://www.nber.org/chapters/c7988

Chapter pages in book: (339 - 354) 


\title{
New Evidence on Trends in the Cost of Urban Agglomeration
}

\author{
Matthew E. Kahn
}

\subsection{Introduction}

The benefits of urban agglomeration cannot take place if city living exposes the population to deadly levels of ambient air pollution and raises the risk of experiencing infectious diseases such as cholera, diarrhea, and dysentery (Melosi 2000). At the turn of the twentieth century, the average white urbanite in the United States paid a ten-year "mortality penalty" for not living in the countryside (Haines 2001). By 1940, big-city investments in water treatment and sanitation significantly reduced the threat of water pollution (Cutler and Miller 2004; Haines 2001).

Over the twentieth century, U.S. big cities have experienced rising and then declining levels of crime and pollution. Ambient air pollution grew sharply over the twentieth century, peaking in the early 1970s and declining over the last thirty years. Urban crime rates have been documented to have risen during the 1970s and 1980s and to have declined sharply since the early 1990s (Levitt 2004; Reyes 2007).

At this point in time, big cities feature more congestion, pollution, and crime than smaller cities (Glaeser 1998; Glaeser and Sacerdote 1999). These nonmarket local public bads can significantly reduce big-city quality of life (Tolley 1974; Blomquist, Berger, and Hoehn 1988; Gyourko and Tracy 1991). In contrast, larger cities offer greater cultural amenities and a better variety of shopping and cuisine options than smaller cities (Waldfogel 2008). Big cities also offer greater possibilities for good matches in the marriage and

Matthew E. Kahn is professor of economics and of public policy at the University of California, Los Angeles, and a research associate of the National Bureau of Economic Research.

This research was supported by the Richard S. Ziman Center for Real Estate at UCLA. I thank Ed Glaeser, Joe Gyourko, Jed Kolko, and two reviewers for useful comments. 
labor markets. This suggests that big cities offer a quality-of-life trade-off: they offer a greater variety of market goods than small cities but suffer from worse levels of nonmarket local public goods.

This chapter examines how the population elasticity of producing local public bads such as crime, pollution, and commute times has changed over time and how it varies across U.S. census regions. In a nutshell, I find that the commute time/population elasticity is relatively small but stable over time. I document sharp, negative time trends in ambient pollution and violent crime in big cities.

In addition to exploring time trends in key determinants of quality of life, this chapter also documents significant geographical variation in the relationship between ambient air pollution and population size and between crime and population size at a point in time. Relative to cities in other regions, the metropolitan areas in the Northeast suffer the highest "big-city premium" with respect to pollution and crime. This chapter also documents that employment suburbanization in major cities has sharply reduced suburban commute times.

Big-city quality-of-life progress along the crime and pollution dimensions means that these cities will have an easier time attracting and retaining the skilled to live there (Glaeser, Kolko, and Saiz 2001). This in turn raises their prospects for future growth.

\subsection{Urban Quality-of-Life Dynamics}

The cross-city quality-of-life literature has used hedonic techniques to compare city quality of life at certain points in time. Leading studies such as Blomquist, Berger, and Hoehn (1988) and Gyourko and Tracy (1991) have estimated cross-city wage and rental hedonic regressions to parse out how much of the cross-city differences in quality standardized wages and rents is due to tied locational amenities such as climate, street safety, and so forth.

While climate is a crucial nonmarket public good, in this chapter, I focus on city attributes that evolve over time. New York City today bears little resemblance to the bankrupt, unsafe New York City of the 1970s. Similar urban rejuvenations can be found in a range of cities, such as Boston, Los Angeles, and San Francisco.

Recent cross-city hedonic wage and real estate research documents overall recent quality-of-life progress in big cities relative to small cities (Glaeser and Gottlieb 2006). They contrast the 1970 and 2000 wage and rent premium data in big and small cities. In 1970, workers with observationally identical demographics were paid higher wages in big cities relative to small cities, but by the year 2000 , this cross-city pattern had reversed, such that quality adjusted wages were lower in big cities relative to small cities. Between 1970 and 2000, home prices increased more in big cities relative to smaller cities. These findings are consistent with the claim that big-city quality of life has improved. 
While metropolitan areas differ along several dimensions, in this chapter, I focus on three major disamenities: namely, commute times, urban air pollution, and crime. Throughout this chapter, I will present new estimates of the cross-sectional relationship between these city attributes and city population size.

Estimates of the relationship between commute times, pollution, crime, and city population size represent important inputs in determining whether the observed dynamics in big city/small overall compensating differentials (as documented by Glaeser and Gottlieb [2006]) can be explained by big-city progress with respect to three classic challenges that these cities face.

To link this chapter's empirical work to the hedonic quality-of-life dynamics literature, suppose that we know the marginal willingness to pay to avoid a small change in commute time, pollution, and crime, and we make the strong assumption that utility is linear in these nonmarket public bads. Define these valuation weights as $b_{\text {commute }}, b_{\text {pollution }}$, and $b_{\text {crime, }}$, respectively. At a point in time $t$, the marginal quality-of-life damage caused by living in a bigger city relative to a smaller city equals $b_{\text {commute }} \times \partial$ Commute $_{t} / \partial$ Pop $_{t}+b_{\text {pollution }} \times$ $\partial$ Pollution $_{t} / \partial$ Pop $_{t}+b_{\text {crime }} \times \partial$ Crime $_{t} / \partial$ Pop $_{t}$. While the estimates of these valuation weights remain contentious, this simple equation highlights this chapter's key empirical goals. I will provide new estimates of these marginal effects at several points in time, and I will estimate how these marginal effects vary across regions.

\subsection{The Commute Time versus City-Size Relationship Over Time}

To document the commute time/city-size relationship and how it has changed over time, I use the Integrated Public Use Microdata Series(IPUMS) Census microdata from the 1 percent 1980, 1990, and 2000 samples. For person $i$ living in city $j$ at time $t$, I estimate:

$$
\log \left(\text { Commute Time }{ }_{j i t}\right)=c_{t}+b_{t} \times \log \left(\text { Pop }_{j t}\right)+b_{t} \times X_{j i t}+U_{j i t} .
$$

The regression results are reported in table 11.1. In this regression, I control for a vector of household-level demographic variables, including the head's age, sex, and socioeconomic status. My sample includes all workers who report positive commute times and who live in a metropolitan area that I could identify in all three of these Census data sets. I am able to identify one hundred metropolitan statistical areas (MSAs) that are geocoded in each of these census years. This sample includes all of the major metropolitan areas. The five smallest metropolitan areas in this sample include Boise City, Idaho; Sarasota, Florida; Modesto, California; Melbourne, Florida; and Pensacola, Florida. Table 11.1 presents two ordinary least squares (OLS) estimates of this pooled cross-sectional regression, and two key findings emerge. In 1980, the elasticity of commute time with respect to metropolitan-area population size was 0.13 . In 1990 and 2000, this elasticity did not change. In the right column of table 11.1, I report the same regres- 
One-way commute time elasticities by city size

\begin{tabular}{lccccc}
\hline & \multicolumn{2}{c}{ All } & & \multicolumn{2}{c}{ Private vehicle } \\
\cline { 2 - 3 } \cline { 5 - 6 } & Beta & Standard error & & Beta & Standard error \\
\hline Log(MSA population) & 0.1379 & 0.0271 & & 0.0906 & 0.0087 \\
Log(MSA population) $\times 1990$ dummy & -0.0018 & 0.0059 & & 0.0071 & 0.0051 \\
Log(MSA population) $\times 2000$ dummy & -0.0052 & 0.0064 & & 0.0120 & 0.0048 \\
Age & 0.0018 & 0.0001 & & 0.0018 & 0.0001 \\
Male & 0.1239 & 0.0092 & & 0.1503 & 0.0080 \\
Duncan socioeconomic index & 0.0014 & 0.0002 & & 0.0013 & 0.0001 \\
Constant & 0.8081 & 0.3348 & & 1.2950 & 0.1363 \\
Observations & $1,400,363$ & & & $1,197,907$ & \\
$R^{2}$ & 0.038 & & & 0.032 & \\
Year dummies & Yes & & & Yes & \\
\hline
\end{tabular}

Note: The dependent variable is the log of the one-way commute time. The data set is the 1 percent IPUMS sample from the 1980, 1990, and 2000 Censuses. The sample includes all workers who live in one of the one hundred metropolitan areas that are identified in the 1980, 1990, and 2000 Census 1 percent samples. The omitted category is a female worker in the year 1980.

sion, but this time it is for the subset of workers who commute by private vehicle. In this case, the city-size elasticity shrinks to 0.09 .

Public transit is a relatively slow commuting mode, and it is more likely to be used in major cities. ${ }^{1}$ In 1980, the average worker in New York City, Chicago, and Los Angeles had a one-way commute time that was 5.9 minutes longer than the average commute time of the one hundred MSAs (29.9 minutes to 24 minutes). In 2000, this differential had not changed, with an average commute time of 32.3 minutes in these three major cities relative to a national average of 26.4 minutes for the sample of one hundred MSAs. It is important to note that across this sample of one hundred metropolitan areas in the year 2000, the average one-way commute time using public transit was forty-four minutes, while the average one-way commute time by private vehicle was twenty-five minutes. In addition, in New York City, Chicago, and Los Angeles, public transit usage is much higher. In the year 2000, 4.1 percent of workers in the one hundred MSAs commuted by public transit, while 20 percent of workers in New York City, Chicago, and Los Angeles commuted by public transit.

To provide some evidence on how commute speeds are affected by city size, public transit use, and location within the metropolitan area, I use microdata from the 2001 National Household Transportation Survey (NHTS). An attractive feature of this data is that it is possible to obtain residential zip

1. These results are roughly in line with cross-city estimates reported in Glaeser (1998). Using 1990 city-level data for the fifty largest cities, he estimates that a doubling of a city's population size is associated with a 1.9 minute increase in the one-way commute. 
code identifiers. I use this information to calculate each metropolitan-area resident's distance to the central business district (CBD). Using information on each respondent's distance to work and commute time allows me to estimate the speed at which they commute to work. Table 11.2 reports three regressions based on equation (2). The dependent variable is the speed at which workers commute as measured in miles per hour. The unit of analysis is person $i$ in metropolitan area $j$ in 2001.

(2) Speed $_{i j}=$ constant $+b \times \log \left(\right.$ MSA Population $\left._{j}\right)+b \times\left(\right.$ Distance to $^{2}$ $\left.\mathrm{CBD}_{i j}\right)+b \times 1\left(\right.$ Commute using Public Transit $\left.t_{i j}\right)+U_{i j}$.

The standard errors are clustered by metro area. In column (1), I only include the metropolitan area's population as the explanatory variable. A doubling of a metro area's population is associated with a reduction in speed of 1.6 miles per hour. In column (2), I control for a worker's residential distance to the CBD. For every extra mile that a household lives from the CBD, its commuting speed increases by 0.45 miles per hour. The third specification reported in table 11.2 demonstrates how slow public transit is. People in big cities are more likely to commute using public transit, and this increases their commute times. All else equal, a worker who commutes using public transit travels 10.5 miles per hour slower than a worker who commutes by car. Note that controlling for whether a worker commutes using public transit shrinks the city-size coefficient from -2.46 to -1.81 . Public transit use in big cities is an important explanation for long commute times.

Population suburbanization and reduced use of public transit in big cities have both helped to increase urbanites' commute speeds. Based on census tract-level data, the average person living in a metropolitan area in 1970 lived

Table 11.2 Commuting speeds in cities based on 2001 NHTS microdata

\begin{tabular}{|c|c|c|c|c|c|c|}
\hline \multirow[b]{3}{*}{ Column } & \multicolumn{6}{|c|}{ Speed measured in miles per hour } \\
\hline & \multicolumn{2}{|c|}{ (1) } & \multicolumn{2}{|c|}{ (2) } & \multicolumn{2}{|c|}{ (3) } \\
\hline & Beta & $\begin{array}{l}\text { Standard } \\
\text { error }\end{array}$ & Beta & $\begin{array}{l}\text { Standard } \\
\text { error }\end{array}$ & Beta & $\begin{array}{c}\text { Standard } \\
\text { error }\end{array}$ \\
\hline $\begin{array}{l}\text { Log(metropolitan-area } \\
\text { population size) }\end{array}$ & -2.2870 & 0.4227 & -2.4625 & 0.2774 & -1.8149 & 0.2067 \\
\hline Distance to CBD & & & 0.4472 & 0.0363 & 0.3847 & 0.0306 \\
\hline Commute using public transit & & & & & -10.5490 & 0.7344 \\
\hline Constant & 62.5491 & 6.1644 & 59.9064 & 3.8177 & 51.6993 & 2.9003 \\
\hline Observations & 25,778 & & 25,778 & & 25,778 & \\
\hline$R^{2}$ & 0.023 & & 0.0680 & & 0.1010 & \\
\hline
\end{tabular}

Note: This table reports three OLS regressions. The unit of observation is a commuter. Standard errors are clustered by metropolitan area. In column (3), the omitted category is a worker who commutes by private vehicle. 
8.72 miles from the $\mathrm{CBD}$, while the average person living in a metropolitan area in the year 2000 lived 11.44 miles from the CBD. Over this same time period, the share of urbanites who commuted using public transit decreased by 10 percentage points. Based on the estimate reported in column (3) of table 11.2, these two trends would increase commute speeds by $(11.44-8.72)$ $\times 0.3847-10.55 \times(0.059-0.121)$, or 1.7 miles per hour.

\subsection{Within Major City Commute Time Differentials}

In the past, when metropolitan-area employment was concentrated in the central business district, urban growth would translate into rising commute times, both because the marginal growth took place at the urban fringe and because the commuters would exacerbate congestion bottlenecks as they sought to get downtown. The ongoing decentralization of employment has helped to alleviate some of these congestion effects (Glaeser and Kahn 2001).

To study within-city trends over time in commuting, I use census tract data from 1980 and 2000 (for details on the data, see Baum-Snow and Kahn [2005]). Figure 11.1 presents results from 1980 and 2000. For all people who live within thirty miles of a CBD, I calculate the share of workers who have

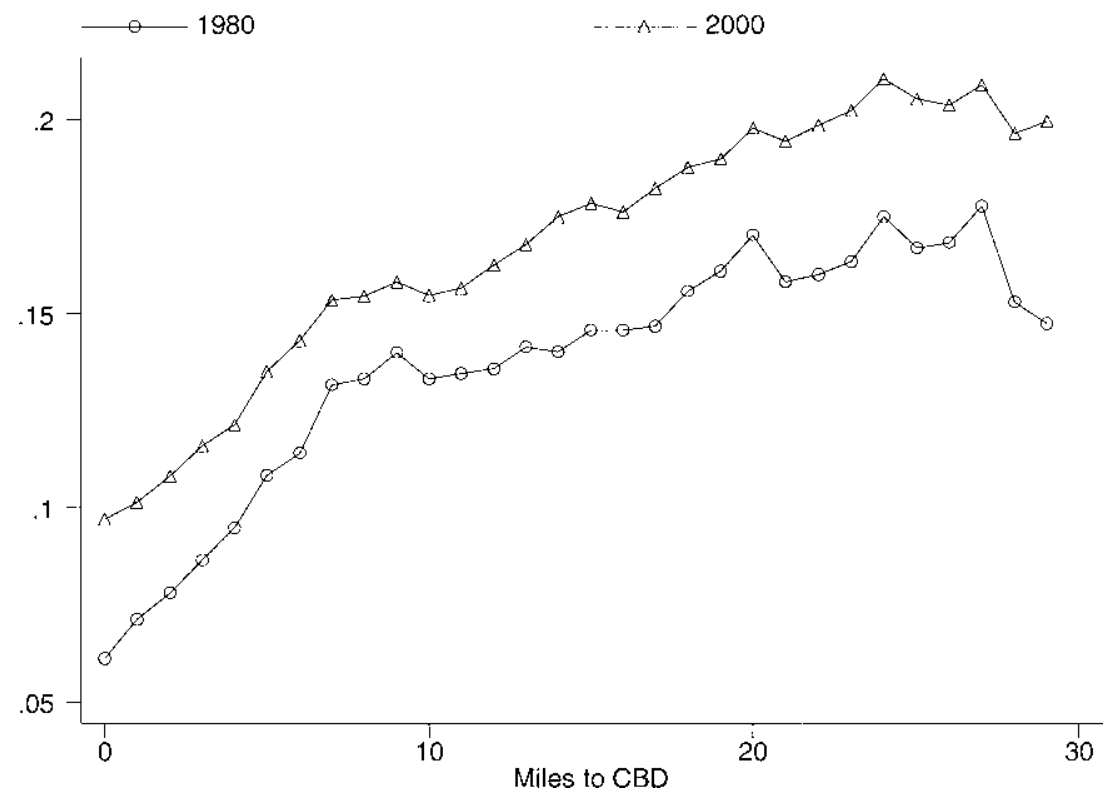

Fig. 11.1 Share of workers whose one-way commute time is over forty-five minutes: All metro areas 
a commute over forty-five minutes long by mileage distance to the CBD of the metro area they live in. The figure's lines are roughly parallel. Very few commuters living close to a CBD have a long commute in 1980 or 2000 . The share with long commutes increases out to about ten miles from the CBD, and then in both years, the slope flattens. It is important to note that in the year 2000, a larger share of commuters do have long commutes relative to the year 1980 . This gap roughly equals 2 percentage points.

Figure 11.2 is identical to figure 11.1, but now I focus only on Chicago, Los Angeles, and New York City. This cut of the data allows me to investigate changes in commuting patterns in the very biggest cities. The first point to note is that the figure does not look like figure 11.1. From zero miles to eight miles from the CBD, the share with a long commute increases, but in the eight-to-twenty-mile range, it declines sharply. In these major cities, these commute times reject the claim that these are monocentric cities.

Figure 11.3 examines the share of workers whose commute is less than twenty-five minutes long in the year 2000 by distance from the CBD. The facts for the major metropolitan areas of Chicago, Los Angeles, and New York City echo those presented in figure 11.2. Starting at zero miles from the CBD, the share of workers with a short commute declines sharply with distance, but at roughly eight miles out, this function reaches its minimum

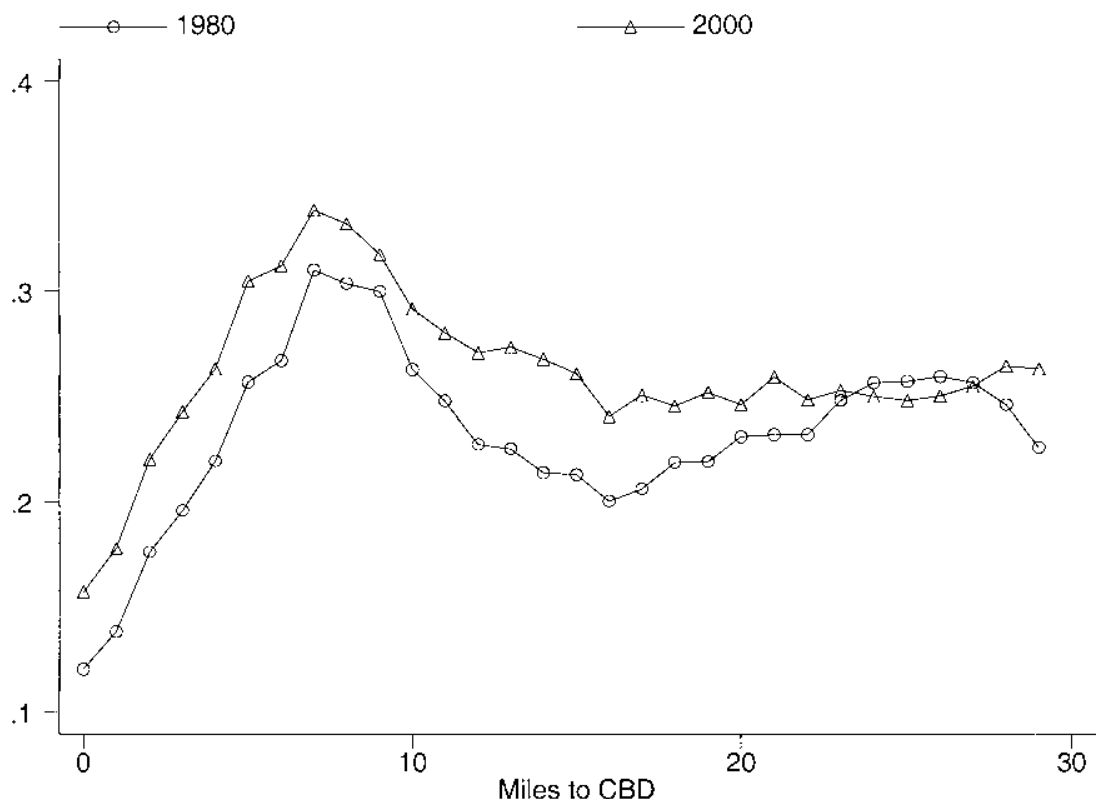

Fig. 11.2 Share of workers whose one-way commute time is over forty-five minutes: Sample includes Chicago, Los Angeles, and New York City 


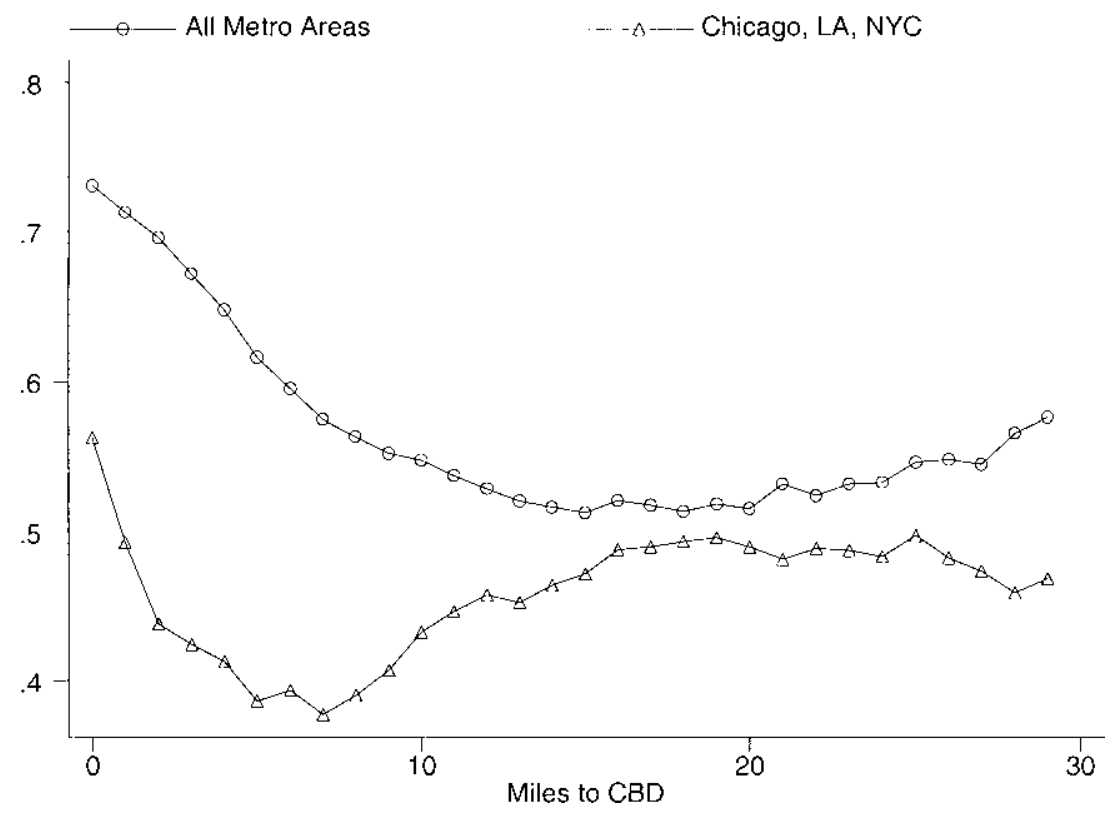

Fig. 11.3 Year-2000 share of commuters with one-way commute less than twentyfive minutes

and turns around, such that workers who live twelve miles from the CBD are much more likely to have a short commute than workers who live eight miles from the CBD. One simple explanation for this pattern is that in these cities, suburban residents work at suburban jobs and are avoiding big-city urban bottlenecks. In contrast, the average MSA worker's probability of having a short commute declines monotonically with distance from the CBD.

Using year-2000 Census data on average commute times by census tract, in figure 11.4, I report average commute times for metropolitan-area workers by miles of distance from their CBD. The figure displays three different lines: one is for all urban workers, one is for workers who live in metropolitan areas with four million people or more, and one is for workers who live in metropolitan areas with less than four million people. The figure highlights that average commute times rise with distance from the CBD. Commute times in big cities take longer on average, but note the nonmonotonic shape. Commute times in big cities decline sharply from seven miles to the CBD out to twenty miles from the CBD. In contrast, average commute times rise in smaller cities over this same mileage interval. This figure highlights the role that employment decentralization in major cities has played in helping suburbanites to enjoy shorter commutes. 


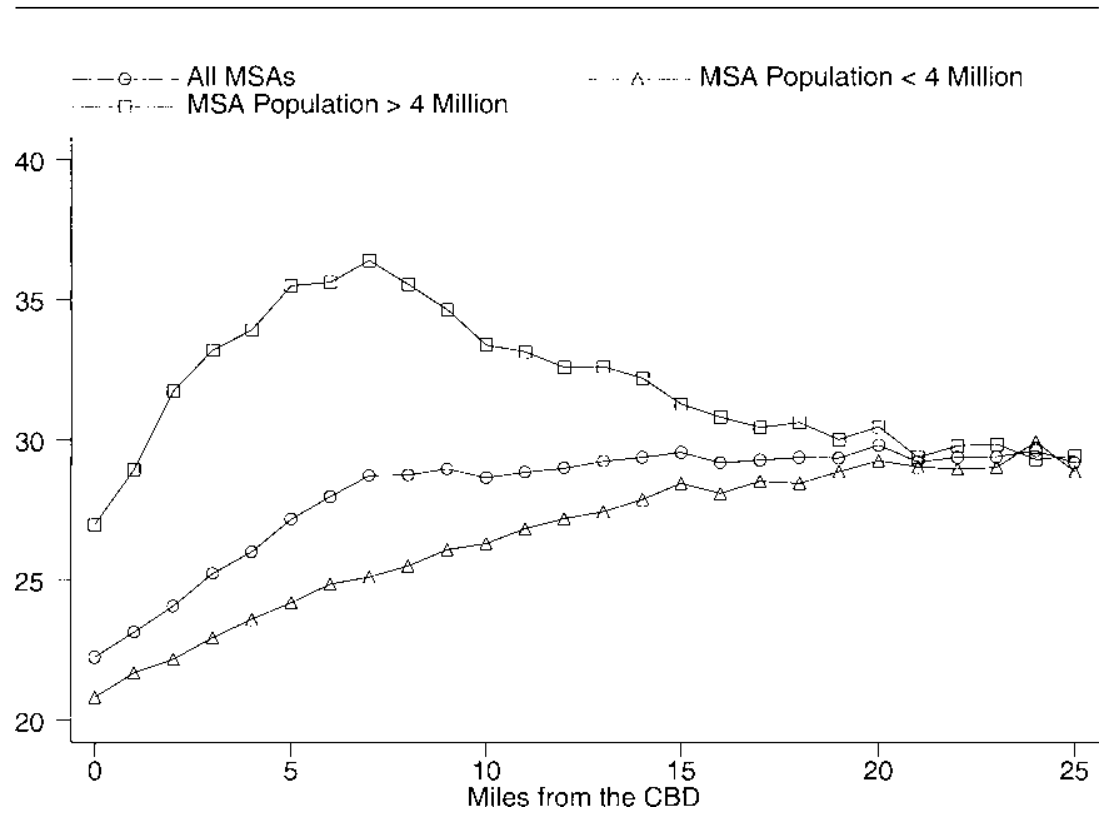

Fig. 11.4 Average commute time in the year 2000 by city size

\subsection{Urban Pollution Progress}

Today, major cities such as Los Angeles and New York City compete to be "green cities". ${ }^{2}$ Such cities seek to enhance their environmental quality to improve public health and to retain the footloose skilled.

A city's pollution level at a point in time is a function of scale, composition, and technique effects. Scale represents a city's population size. While urban economists have emphasized the role of the sheer scale of activity in imposing social costs, environmental economists have countered that composition and technique effects can offset the externality costs of population growth (Kahn and Schwartz 2008). Composition effects focus on the major industries that are clustered in a city at a point in time. Technique effects are defined as the emissions per unit of activity from various forms of capital, such as cars, power plants, and factories. A city could have many steel mills (a brown composition), but if the steel mills released few emissions per dollar of output (a green technique), then the city may not be polluted.

Composition effects have played an important role in "greening" U.S. cities. The rise and decline of urban manufacturing was an important factor driving urban pollution levels in the twentieth century. In the twentieth cen-

2. For example, see New York City's plan, available at: http://www.nyc.gov/html/planyc2030/ html/greenyc/greenyc.shtml, and Los Angeles's plan, available at http://www.lacity.org/ead/ EADWeb-AQD/GreenLA_CAP_2007.pdf. 


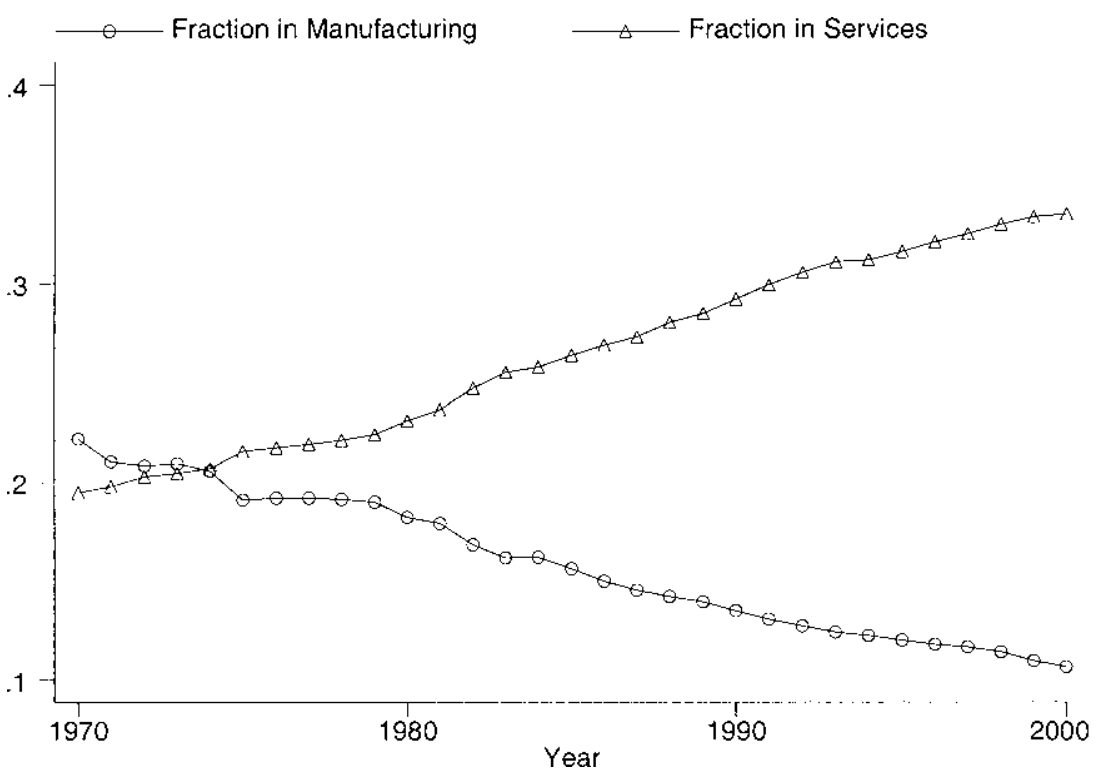

Fig. 11.5 Employment trends in U.S. metropolitan areas

tury, the rise of Pittsburgh as a steel capital had the unintended consequence of sharply increasing particulate levels. An unintended silver lining of the U.S. Rust Belt's decline in the 1960s and 1970s has been to sharply improve environmental quality in heavily industrial cities such as Pittsburgh, Pennsylvania, and Gary, Indiana (Kahn 1999). Between 1969 and 2000, the number of manufacturing jobs in New York county (Manhattan) declined from 451,330 to 146,291 . Similar declines in manufacturing have taken place in London, England. There are large public health gains from removing older, polluting manufacturing plants from heavily populated areas. As shown in figure 11.5, metropolitan areas in the United States have experienced a composition shift as the share of workers in urban manufacturing has declined and as the service sector's share has grown.

Technique is the final key determinant of urban pollution levels. Technique refers to the emissions rates of different technologies used within the cities. Electric utilities are more likely to be located in counties with a larger population (Kahn 2009). Coal-fired power plants are major polluters. Many of these are located in the Midwest in states such as Ohio. Newer cohorts of electric utilities feature emissions factors (emissions per unit of power generation) that are 50 percent lower than older power plants (Burtraw and Evans 2003).

Vehicle emissions progress offers another example of the greening of urban technique. Cars cluster where people cluster, and the rise of private 
vehicle use contributed to rising levels of ambient smog in cities. Under the Clean Air Act, new vehicles only faced stringent emissions standards starting in the early 1970s. As vehicles built before 1975 have been scrapped, the average vehicle on the roads has become so much cleaner that many major cities, such as Los Angeles, have experienced significant smog progress, despite ongoing growth in population and miles driven (Kahn and Schwartz 2008). Between 1980 and 2000, Los Angeles county's population grew by 29 percent, while total automobile mileage grew by 70 percent. Yet, the number of days per year exceeding the federal one-hour ozone standard declined from about 150 days per year at the worst monitoring stations in this metropolitan area during the early 1980s down to twenty to thirty days per year today (Kahn and Schwartz 2008).

I now present some new estimates of the time trend in urban ambient pollution levels. Using county/year-level data, in table 11.3, I estimate five pollution-production regressions. I use the U.S. Environmental Protection Agency's Annual Summary Table Query database to examine the relationship between urban population size and ambient pollution levels between 1973 and $2000 .{ }^{3}$ The sample includes counties in metropolitan areas that have at least one monitoring station operating. The estimation equation for county $j$ in year $t$ is:

$$
\begin{aligned}
\log \left(\text { Ambient Pollutant }_{j t}\right)= & c+b_{1} \times \log \left(\text { Population }_{j t}\right) \\
& +b_{2} \times \log \left(\text { Population }_{j t}\right) \times \text { Region }_{j} \\
& +b_{3} \times \text { Trend }_{t}+U_{j t} .
\end{aligned}
$$

The time trend results document the overall progress. Ambient carbon monoxide has declined by 4.2 percent per year. Particulate matter has improved by over 2.1 percent per year, and ambient urban PM10 (particulate matter of ten microns or smaller in diameter) levels have fallen by 3.2 percent. I find no evidence supporting the claim that bigger cities have experienced a more differential time trend than smaller counties. For carbon monoxide, total suspended particulates (TSP), and smaller particulate matter (PM10), I find the largest county population-elasticity effects. The regressions indicate that the pollution/population elasticity is consistently largest in the Northeast relative to other regions.

\subsection{Urban Crime Progress}

Crime is a key urban disamenity. Big-city crime rates are higher than smaller cities (Glaeser and Sacerdote 1999), but crime has been declining in big cities since in the early 1990s. An empirical literature continues to debate 


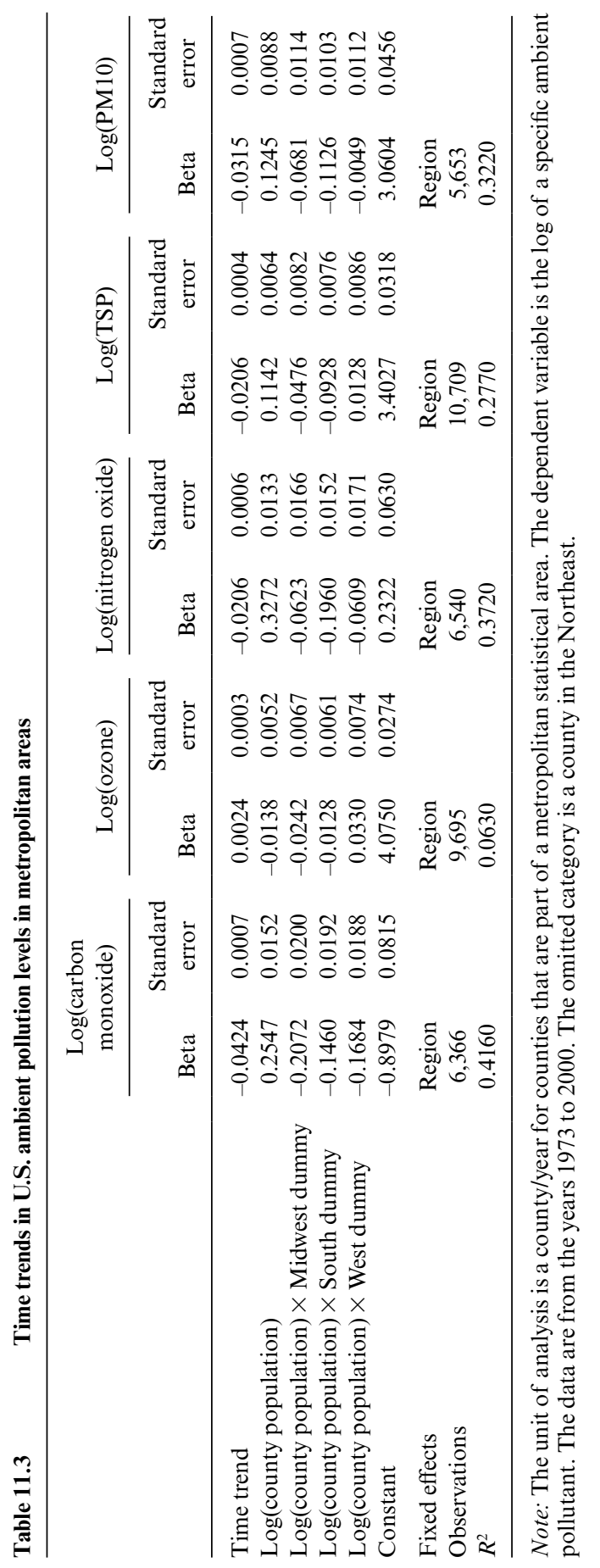


what role abortion, lead, crack cocaine, police hires, and incapacitation has played in explaining this trend (Levitt 2004; Reyes 2007).

In this section, I present new estimates of crime trend rates over the time period from 1994 to 2002 for counties located in metropolitan areas. I report results on the murder count and the violent crime count. The unit of analysis is county $j$ in year $t$. I estimate equation (4):

$$
\begin{aligned}
\text { Crime Per-Capita } & =c+b_{j t} \times \log \left(\text { Pop }_{j t}\right)+b_{2} \times \log \left(\text { Pop }_{j t}\right) \times \text { Region }_{j} \\
& +b_{3} \times \operatorname{trend}_{t} \times \log \left(\text { Pop }_{j t}\right) \times \text { Region }_{j}+U_{j t} .
\end{aligned}
$$

The data source is the Federal Bureau of Investigation county crime database (http://fisher.lib.virginia.edu/collections/stats/crime/). The results reconfirm the well-known fact that per capita crime victimization is higher in more populated areas. In terms of quality of life in big cities, the good news is that this effect is sharply declining over time. The Northeast is the region with the steepest crime/population relationship.

The estimates reported in table 11.4 provide insights into big city/small city quality-of-life convergence. I use the OLS estimates reported in column (1) to conduct a difference-in-difference thought experiment. Consider two different counties that are located in a metropolitan area. The first has a population of 200,000 , and the second has a population of 1 million. Based on the estimates reported in column (1) of table 11.4, between 1994 and 2002 , the murder rate per 1,000 people between these two counties declined by $0.018[0.0148 \times \log (5)-(0.0148-0.0014 \times 8) \times \log (5)]$. Given the standard estimate of a $\$ 6$ million value of a statistical life, each person in the million-person county would be willing to pay $\$ 108$ for this reduction in risk, and family of four would be willing to pay $\$ 432$ in after-tax income for this reduction in risk. While sizable, this calculation reveals that even crime reductions by themselves cannot explain the large overall convergence in wages and divergence in home prices that Glaeser and Gottlieb (2006) document to have taken place over the last thirty years. In table 11.3, I documented significant negative time trends in urban air pollution. While households certainly value such reductions, the overall gains in big cities versus small cities in pollution are unlikely to exceed the total willingness to pay for the crime risk reduction.

\subsection{Conclusion}

Congestion, pollution, and crime represent three important factors that discourage urban agglomeration. Unlike other spatial amenities such as climate, these local public bads change over time, and this chapter has used a variety of data sets to examine their time trends in major cities in the United States. This chapter has used a production function approach to estimate how city size is associated with local public bads at different points in time and across U.S. regions. 


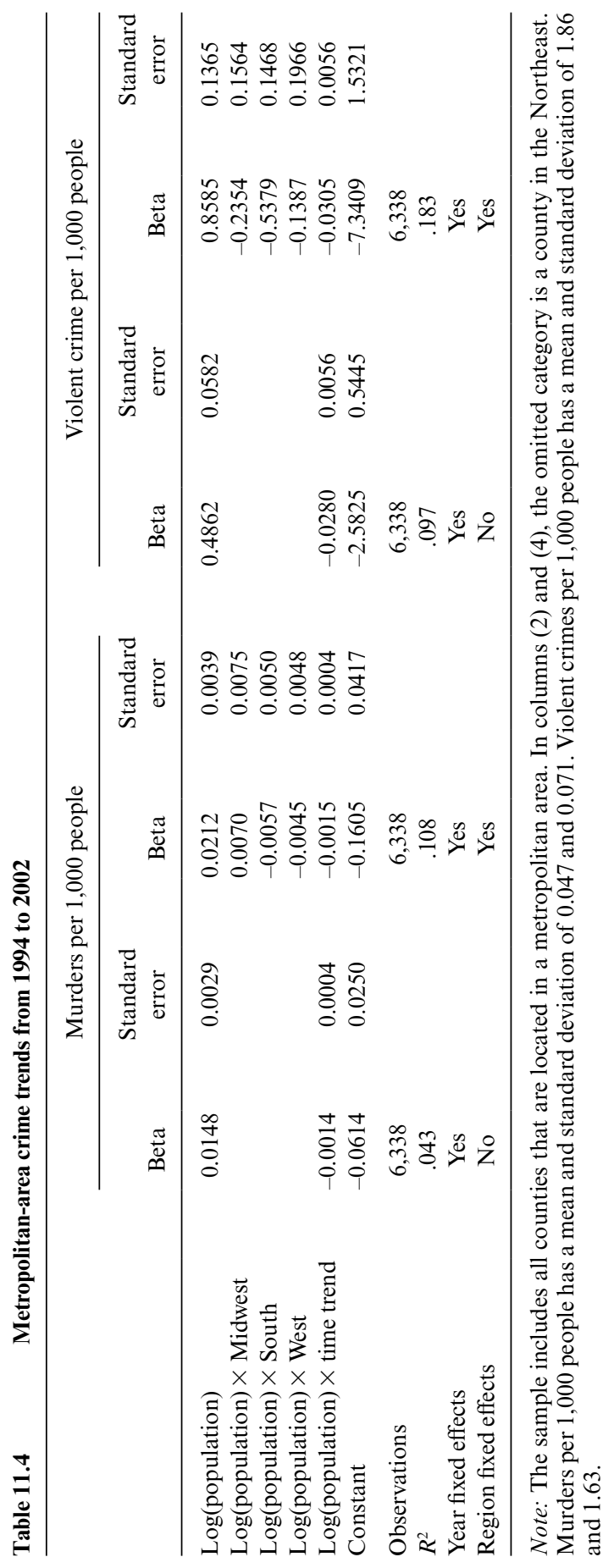


Big cities have enjoyed sharp, recent reductions in ambient pollution and crime. This chapter has documented that the commute time/city-size relationship is small (an elasticity of 0.13 ) and stable over time.

This chapter's results complement a recently revealed preference literature that has used cross-city hedonic approaches to infer city quality of life (Glaeser and Gottlieb [2006] and Albouy [2008]). While I have documented crime and pollution progress, it is not clear whether these gains are large enough to fully explain the big-city quality-of-life progress documented by these other authors.

One possible reconciliation of these findings is that a social multiplier effect is at work. Consider New York City during the 1990s. As crime fell, the city made a sharp comeback. Street safety and rising incomes may work synergistically to encourage more upscale stores, restaurants, and nightlife to open. Put simply, market goods and city quality of life are complements in providing consumer utility. A hedonic approach that solely focuses on conducting a separable decomposition by teasing out each of these effects individually is likely to underestimate the overall impact of these factors on urban quality of life. The net effect of crime and pollution reductions is stronger cities. This reduction in the cost of "city bigness" means that cities can grow and enjoy the beneficial effects of agglomeration.

This study has focused solely on U.S. cities. In developing countries where government regulation may be ineffective, is the marginal social cost of megacity-size growth at a point in time much larger?

\section{References}

Albouy, D. 2008. Are big cities really bad places to live? Improving quality-of-life estimates across cities. NBER Working Paper no. 14472. Cambridge, MA: National Bureau of Economic Research, November.

Baum-Snow, N., and M. E. Kahn. 2005. Effects of urban rail transit expansions: Evidence from sixteen cities from 1970-2000. Brookings-Wharton papers on urban affairs, vol. 6, ed. G. Burtless and J. R. Pack, 147-206. Washington, DC: Brookings Institution Press.

Blomquist, G., M. Berger, and J. Hoen. 1988. New estimates of quality of life in urban areas. American Economic Review 78 (1): 89-107.

Burtraw, D., and D. Evans. 2003. The evolution of NOx control policy for coal-fired power plants in the United States. RFF Working Paper no. 03-23. Washington, DC: Resources for the Future.

Cutler, D. M., and G. Miller. 2004. The role of public health improvements in health advances: The 20th century United States. NBER Working Paper no. 10511. Cambridge, MA: National Bureau of Economic Research, May.

Glaeser, E. L. 1998. Are cities dying? Journal of Economic Perspectives 12 (2): $139-60$.

Glaeser, E. L., and J. Gottlieb. 2006. Urban resurgence and the consumer city. Urban Studies 43 (8): 1275-99. 
Glaeser, E., and M. E. Kahn. 2001. Decentralized employment and the transformation of the American city. In Brookings-Wharton papers on urban affairs, vol. 2, ed. W. G. Gale and J. R. Pack, 1-63. Washington, DC: Brookings Institution Press.

Glaeser, E., J. Kolko, and A. Saiz. 2001. Consumer city. Journal of Economic Geography 1 (1): 27-50.

Glaeser, E., and B. Sacerdote. 1999. Why is there more crime in cities? Journal of Political Economy 107 (S6): S225-S229.

Gyourko, J., and J. Tracy. 1991. The structure of local public finance and the quality of life. Journal of Political Economy 91 (4): 774-806.

Haines, M. 2001. The urban mortality transition in the United States, 1800-1940. NBER Historical Working Paper no. 134. Cambridge, MA: National Bureau of Economic Research, July.

Kahn, M. E. 1999. The silver lining of Rust Belt manufacturing decline. Journal of Urban Economics 46 (3): 360-76.

-2009. Regional growth and exposure to nearby coal fired power plant emissions. Regional Science and Urban Economics 39 (1): 15-22.

Kahn, M. E., and J. Schwartz. 2008. Urban air pollution progress despite sprawl: The "greening" of the vehicle fleet. Journal of Urban Economics 63 (3): 775-87.

Levitt, S. D. 2004. Understanding why crime fell in the 1990s: Four factors that explain the decline and six that do not. Journal of Economic Perspectives 18 (1): 163-90.

Melosi, M. V. 2000. The sanitary city: Urban infrastructure in America from colonial times to the present. Baltimore: Johns Hopkins University Press.

Reyes, J. W. 2007. Environmental policy as social policy? The impact of childhood lead exposure on crime. B. E. Journal of Economic Analysis and Policy 7 (1): 1796.

Tolley, G. S. 1974. The welfare economics of city bigness. Journal of Urban Economics 1 (3): 324-45.

Waldfogel, J. 2008. The median voter and the median consumer: Local private goods and population composition. Journal of Urban Economics 63 (2): 567-82. 